\title{
What Makes Annuitization More Appealing?
}

\author{
John Beshears, \\ Stanford University and NBER \\ James J. Choi, \\ Yale University and NBER \\ David Laibson, \\ Harvard University and NBER \\ Brigitte C. Madrian, and \\ Harvard University and NBER

\section{Stephen P. Zeldes} \\ Graduate School of Business, Columbia University, and NBER
}

\begin{abstract}
We conduct and analyze two large surveys of hypothetical annuitization choices. We find that allowing individuals to annuitize a fraction of their wealth increases annuitization relative to a situation where annuitization is an "all or nothing" decision. Very few respondents choose declining real payout streams over flat or increasing real payout streams of equivalent expected present value. Highlighting the effects of inflation increases demand for cost of living adjustments. Frames that highlight flexibility, control, and investment significantly reduce annuitization. A majority of respondents prefer to receive an extra "bonus" payment during one month of the year that is funded by slightly lower payments in the remaining months. Concerns about later-life income, spending flexibility, and counterparty risk are the most important self-reported motives that influence the annuitization decision.
\end{abstract}

\section{Keywords}

annuity; pension; retirement income; framing

\section{Introduction}

Many households resist annuitization. In U.S. defined benefit (DB) pension plans that offer a lump-sum option, between $50 \%$ and $75 \%$ of eligible DB benefits are taken as a lump sum, even though the annuity is the default option and opting out requires time-consuming paperwork (Mottola and Utkus, 2007; Benartzi, Previtero, and Thaler, 2011; Previtero,

\footnotetext{
(C) 2013 Elsevier B.V. All rights reserved.
}

Publisher's Disclaimer: This is a PDF file of an unedited manuscript that has been accepted for publication. As a service to our customers we are providing this early version of the manuscript. The manuscript will undergo copyediting, typesetting, and review of the resulting proof before it is published in its final citable form. Please note that during the production process errors may be discovered which could affect the content, and all legal disclaimers that apply to the journal pertain. 
2012; Banerjee 2013). In defined contribution (DC) savings plans, only $10 \%$ of participants who leave their job after age 65 annuitize their assets (Johnson, Burman, and Kobes, 2004). This resistance to annuitization is referred to as the "annuitization puzzle" (Modigliani, 1986), since the benefit of buying insurance against outliving one's savings should create strong demand for annuities (Yaari, 1965; Davidoff, Brown, and Diamond, 2005).

Researchers have explored a variety of rational motives that could explain the low demand for annuities, such as adverse selection (Mitchell et al., 1999; Finkelstein and Poterba, 2004), bequest motives (Friedman and Warshawsky, 1990; Brown, 2001; Inkmann, Lopes, and Michaelides, 2011; Ameriks et al., 2011; Lockwood, 2012), uncertain healthcare expenses (Pang and Warshawsky, 2010; Ameriks et al., 2011; Poterba, Venti, and Wise, 2011), annuity prices (Warner and Pleeter, 2001; Fitzpatrick, 2012), means-tested government benefits (Pashchenko, 2010; Bütler, Peijnenburg, and Staubli, 2011), and the annuity embedded in Social Security and defined-benefit pension plans (Bernheim, 1991; Dushi and Webb, 2004; Beshears, Choi, Laibson, and Madrian, 2011).

In this paper, we take no stand on how much of the annuitization puzzle remains after accounting for these rational motives. We instead focus on the elasticity of annuity demand with respect to annuity product design and choice architecture. ${ }^{1}$ To study these issues, we fielded two large surveys in which we elicited hypothetical annuitization choices from individuals aged 50 to 75 . We examine 1) what factors people say are important to their annuitization choices, 2) how offering "partial annuitization," rather than an all-or-nothing choice, influences outcomes, 3 ) individual preferences over the intertemporal slope of annuity payouts, 4) whether altering the framing ${ }^{2}$ used to describe options influences annuitization choices, and 5) whether there is demand for an annuity product that makes an extra "bonus" payment during one month of the year that is funded by slightly lower payments in the remaining months.

The use of surveys such as these has advantages and disadvantages. On the positive side, we can ask questions that directly measure specific preferences, including preferences for products not available on the market. We can also examine choices in economic environments that differ from the current one. On the negative side, the choices people make do not influence their actual life outcomes, so the results may not correspond to the choices people would make in real-life settings. Surveys like ours provide a starting point for designing field experiments with larger stakes. ${ }^{3}$

Five findings emerge from our surveys. First, there are three considerations that respondents report being most important for their decision about whether or not to annuitize: a desire to "make sure I have enough income later in life," a desire for "flexibility in the timing of my

\footnotetext{
${ }^{1}$ Other authors have also studied the role of behavioral factors in annuity choice such as recent stock market returns (Chalmers and Reuter, 2012; Previtero, 2012) and framing Brown, 2008; Brown et al., 2008; Agnew et al., 2008; Brown, Kapteyn, and Mitchell, 2012).

${ }^{2}$ We abuse the "framing" terminology slightly by using it to describe some treatments that not only present the choice in a different way, but also provide additional information.

${ }^{3}$ Arguably, survey responses from those who are more likely to be in a position to purchase annuities would correspond more closely to real-life choices. All of our results on framing treatment effects and demand for alternative annuity products are similar when restricting the sample to those who have net worth above the sample median.
} 
spending," and being "worried about [the] company not being able to pay me in the future." Current regulations ban insurance companies from mentioning back-stop state funds in their marketing of annuity products. While such bans may reduce moral hazard problems by encouraging consumers to be selective, they may also have the perverse effect of decreasing annuity demand. We provide new evidence that this latter effect is important.

Second, we find that a substantial fraction of people choose partial annuitization when it is offered, and that offering partial annuitization rather than an "all-or-nothing" annuitization choice increases both the percentage of people choosing any annuitization and the average percentage of pension balances that are annuitized. Many DB pension plans offer individuals the choice between taking a lump sum and an annuity. ${ }^{4}$ The U.S. Treasury Department recently proposed a new regulation to make it easier for DB plans to offer a combination of an annuity and a lump sum (Federal Register, 2012). Our findings suggest this proposal will increase annuitization in plans that already offer a lump sum withdrawal option.

Third, we find that holding the present value of expected payments fixed, very few respondents choose declining real income paths. Our respondents prefer flat or rising real income paths. This result underscores how puzzling the dearth of inflation-indexed annuities in the marketplace is. This result also contrasts with the empirical fact that holding household composition fixed, real consumption declines by about $2 \%$ per year during retirement (Hurd and Rohwedder, 2011). We also find that making salient the effects of inflation on real payout values increases the demand for cost of living adjustments (COLAs).

Fourth, we find that two framing changes significantly reduce demand for annuitization relative to a neutral frame: one that focuses on flexibility and control, and a second that focuses on investment attributes. Four other framing changes do not have a significant effect on annuitization: explaining that the annuity being offered is a better deal than what could be purchased on the open market, presenting the total expected undiscounted lifetime payments from the annuity, explaining that the annuity provides insurance against outliving one's savings, and explaining that the annuity transfers money from states where one is dead and the value of money is low to states where one is alive and the value of money is high.

Finally, we find that $60 \%$ of our subjects prefer a product that pays an annual bonus in a month of their choosing over a product with a traditional uniform monthly payout. Annual bonuses expand annuitants' control over their high-frequency payout streams without jeopardizing the low-frequency withdrawal restrictions that make longevity insurance possible. The preference for such a product is consistent with subjects' responses that wanting "flexibility in the timing of my spending" is an important factor in their annuitization decision. Allowing more customization of payout streams may increase annuity demand. Other customization schemes are easy to imagine, such as multiple intrayear bonuses or age-contingent payout patterns.

\footnotetext{
${ }^{4}$ A 2011 Aon Hewitt survey of 227 DB plan sponsors found that over 40\% offered a lump sum option, and over $20 \%$ more responded that they were "very likely to implement" or "somewhat likely to implement" a lump sum payment option in the future (Aon Hewitt, 2011). It is thought that many employees perceive the annuitization versus lump sum choice as being an "all-or-nothing" choice (http://www.treasury.gov/press-center/press-releases/Documents/020212\%20Retirement\%20Security\%20Factsheet.pdf).
} 
The remainder of the paper is structured as follows. In Section II, we describe our two surveys. In Section III, we present summary statistics on our sample, and in Section IV, we present our empirical results. Section V concludes by discussing the implications of our findings for the design of pensions and annuity products.

\section{Survey design}

We designed two surveys and retained the online survey firm Toluna to administer them to 1,000 (Survey 1) and 4,130 (Survey 2) U.S. residents ages 50-75 in August 2011 and June 2012, respectively. ${ }^{5}$ U.S. macroeconomic conditions were similar in both periods, characterized by a tepid recovery from a deep recession. The seasonally adjusted trailing one-year GDP growth rate was $1.6 \%$ in the third quarter of 2011 and $2.1 \%$ in the second quarter of 2012. The unemployment rate was $9.0 \%$ in August 2011 and 8.2\% in June 2012. The trailing one-year S\&P 500 total return was higher at the beginning of August 2011 than at the beginning of June 2012 (19.7\% versus $-0.4 \%) .{ }^{6}$ The median times taken to complete the surveys were 13 minutes (Survey 1) and 8 minutes (Survey 2). Participants in both surveys made hypothetical choices about pension income in retirement. They then ranked the importance of different reasons for their choices and answered a set of demographic questions during the same online session. The full surveys are available in an online appendix.

\section{A. Survey 1}

Survey 1 asked participants to make choices under the following hypothetical scenario: "Just before you retire at age 65 , you are working for a company that will give you pension payments every month for the rest of your life after you retire. This income is guaranteed, but the payments will stop when you die. You will also receive Social Security benefits every month for the rest of your life after you retire." Note that this scenario is like that of a traditional DB pension plan.

Because one of the main issues we wished to explore in this survey was preferences over real annuity payment growth rates, we told respondents to assume that inflation would be $2 \%$ for the rest of their lives. We described inflation as follows: "With inflation, prices rise, so you get less for your money than you used to. For example, suppose a basket of groceries costs you $\$ 100$ today. A year later, the same groceries will cost you $\$ 102$. The price of the groceries has gone up because there has been inflation." They were also told that "the interest rate will be $5 \%$ for the rest of your life."

Participants made choices about the intertemporal slope of their annuity payouts, whether to receive intra-year "bonus" payments, and how much of their pension stream to cash out and receive as a lump sum. In each case, the present value of the options' expected payouts was $\$ 330,000$, based on the stated interest rate and Social Security mortality tables (averaging male and female mortalities together). ${ }^{7}$ In calculating annuity payouts, we included no fees

\footnotetext{
${ }^{5}$ Participants were part of a large panel maintained by Toluna who are paid for their participation in each survey. We ran two separate surveys because our research program evolved over time.

${ }^{6}$ Based on the evidence of Previtero (2012), it is possible our respondents' baseline desire to annuitize was lower in Survey 1 than in Survey 2 because of the higher prior stock market return in August 2011.
} 
or markups for costs. In order to avoid having responses be influenced by any negative association participants might have with existing annuities, nowhere in the survey did we use the word "annuity" or "annuitization." 8

Slope of annuity payouts-In the first question, participants were told: "Suppose the company lets you choose between the following two retirement income options. The total cost to the company of providing these lifetime payments to you is expected to be the same under either option." The two options were the following:

A. Match-Inflation Income: "Your first year of monthly payments will sum to $\$ 24,200$. Your monthly payments will rise by $2 \%$ each year for the rest of your life. The increase in your payments will match the increase in prices (inflation)."

B. Steady Income: "Your first year of monthly payments will sum to $\$ 29,000$. Your monthly payments will stay the same for the rest of your life. Because inflation is $2 \%$ each year, the amount you can buy with your income will fall by $2 \%$ each year."

Below these descriptions and before participants were asked to make their choice, subjects were shown three graphs. The first (see Figure 1) was a graph depicting the likelihood that a person aged 65 today will live to at least age $70,75,80,85,90,95$, and 100. The graph's mortality probabilities were the average of male and female mortalities. The second was a graph showing how much something that costs $\$ 1$ today would cost in the future, from ages 65 to 100 (see Figure 2). The third graph (see Figure 3) showed the yearly nominal amount received under each option from ages 65 to 100 .

Participants were then asked to make another choice between two options:

A. Match-Inflation Income, as described in the previous question

B. High-Growth Income: "Your first year of monthly payments will sum to $\$ 19,900$. Your monthly payments will grow by $4 \%$ every year. The increase in these payments will be larger than the increase in prices (inflation)."

Between the description of the options and where participants were to indicate their choice, we showed a graph depicting the yearly nominal amount received under each option from age 65 to 100, and we provided hyperlinks to the previously shown graphs of mortality probabilities and inflation in case participants wished to review them.

Bonus payments-Participants were asked two questions about the addition of bonus payments to their income options. The first question asked participants to choose between the following two options:

\footnotetext{
${ }^{7}$ The mortality data came from "Life Tables for the United States Social Security Area 1900-2100," Actuarial Study No. 120, which can be found at http://www.socialsecurity.gov/OACT/NOTES/as120/TOC.html.

${ }^{8}$ The cost of not using the terms "annuity" and "annuitization" is the risk that participants who were familiar with the terms could have become confused about whether our failure to use them implied that the product being offered was something different from an annuity.
} 
A. Match-Inflation Income: "In the first year, you will receive $\$ 2,000$ every month. This monthly payment will grow by $2 \%$ every year for the rest of your life, matching the increase in prices."

B. Match-Inflation Income with Bonuses: "In the first year, you will receive $\$ 1,900$ in every month except for one, when you will get $\$ 1,900$ plus an extra $\$ 1,200$. You can choose in which month the $\$ 1,200$ bonus is paid. This month might be a time when you often want to spend extra. For example, you might like to travel somewhere warm or spend extra money during the December holiday season. The regular monthly payments and the bonus will each grow by $2 \%$ every year for the rest of your life."

Participants were told, "The total cost to the company of providing these lifetime payments to you is expected to be the same under either option." Participants who chose MatchInflation Income with Bonuses were asked to choose in which month they would like the bonus to be paid.

Participants were then asked to choose between the Match-Inflation Income plan and an income stream with an annual bonus that declined at the end of each decade of life. Again, both payment paths had the same expected present value. We wished to see whether a declining intertemporal payout slope would be more appealing if the decline were justified as a declining travel bonus. The description of the declining bonus was as follows:

B) Match-Inflation Income with Travel Bonuses: "You will receive \$1,800 every month in the first year. These monthly payments will grow $2 \%$ each year for the rest of your life. From age 65 to 69 , you will receive an extra $\$ 3,000$ every June to use for traveling (or whatever else you want). During your 70s, you will receive an extra $\$ 2,000$ every June. During your 80s, you will receive an extra $\$ 1,000$ every June. Because you probably won't be doing much traveling in your 90s, there is no travel bonus after age 89."

Lifetime income stream versus a lump sum-We included three questions asking participants to choose what percent of their annuity benefit to cash out as a lump sum. The first question asked participants about the Match-Inflation income stream, offering three cash-out options: A) "0\% Cash Out," which gave participants monthly payments that summed to $\$ 24,200$ in the first year and increased $2 \%$ annually, but no lump sum payout, B) "50\% Cash Out," which gave participants $\$ 165,000$ immediately plus monthly payments that summed to $\$ 12,100$ in the first year and increased $2 \%$ annually, and C) "100\% Cash Out," which gave participants $\$ 330,000$ immediately and no other payment for the rest of their lives. Participants were told the three options had the same expected costs to the company. Participants were shown a graph (see Figure 4) of the nominal annual payouts they would receive (excluding any lump-sum payment) under each option, from ages 65 to 100 .

The second and third questions asked about cash-out rates for the Steady Income and HighGrowth Income annuities described above, letting participants choose in each case among "0\% Cash Out," "50\% Cash Out," and "100\% Cash Out" options after seeing a graph of the 
nominal yearly payout amounts (excluding any lump sum) they would receive from ages 65 to 100 under each option.

Exit questions-After answering all of the annuity choice questions, participants were asked to rate on a six-point Likert scale ( 0 for not important, 5 for very important) the importance of eleven potential reasons for their cash-out choices. Participants were also asked about their life expectancy relative to the average person of their age and a set of demographic questions. The survey concluded with two questions related to the clarity of the survey. The first asked whether respondents thought the questions were clear or confusing on a scale between 0 (completely clear) and 5 (completely confusing). The second question had an open-response box for respondents to explain what, if anything, they found unclear or confusing. Eighty-seven percent of Survey 1 participants reported that the survey was "clear" or "mostly clear," whereas less than $1 \%$ reported the survey to be "mostly confusing" or "completely confusing" (see Table 1).

\section{B. Survey 2}

In Survey 2, participants were also asked to make annuitization choices based on a hypothetical retirement scenario. This scenario, which is different than the one presented in Survey 1, was described in the first page of the survey:

"Suppose that you are 65 years old. You are about to retire and have accumulated $\$ 500,000$ in the pension plan at your current employer. Your employer wants to know whether you prefer to receive this balance as a lump sum payment right now (in other words, a single $\$ 500,000$ payment) or as a stream of fixed payments over your lifetime, which your employer calls the guaranteed lifetime income option. This stream of fixed payments is based on current market interest rates. The fixed payments won't change in the future even if market interest rates do change."

This wording describes the pension benefit as a dollar accumulation rather than as an accrued income stream. Thus, Survey 2 puts the respondent in a setting more like that of a cash balance or DC pension plan, rather than the traditional DB setting of Survey 1. We also put respondents in their current macroeconomic environment, with all its uncertainties, instead of fixing the future inflation and interest rates as in Survey 1. We made this choice because we wished to study the demand for COLAs, and a significant benefit of a COLA is the hedge it provides against inflation risk.

In Survey 1, we provided only single life annuities, regardless of marital status. In Survey 2, we offered single life annuities to unmarried respondents, and joint and 100\% survivor annuities to married respondents. As in Survey 1, nowhere in Survey 2 was the word "annuity" or "annuitization" used. The annuity option was described throughout the survey as a "guaranteed lifetime income option."

We based Survey 2's annuity payouts on actual price quotes from Western National Life Insurance as of March 1, 2012 for a $\$ 500,000$ annuity. ${ }^{9}$ For participants who were single, we averaged the monthly payout for the male single life annuity $(\$ 2,790.74)$ and the female

\footnotetext{
${ }^{9}$ At that time, this was the most competitive quote on the Hueler Income Solutions website, incomesolutions.com.
} 
single life annuity $(\$ 2,627.87)$ and multiplied the average by $110 \%$. For participants who were married, we multiplied the joint and $100 \%$ survivor annuity monthly payout of $\$ 2,378.20$ by $110 \%$. We multiplied the monthly payouts by $110 \%$ to account for the likelihood that an annuity purchased through an employer charges lower fees and to ensure that the annuity we were offering would be more generous than anything available on the open market - a feature necessary for the Good Deal treatment described below. The final monthly payout offered for somebody annuitizing $100 \%$ of his or her balances was $\$ 2,981$ per month for single survey participants and \$2,616 for married participants.

Participants were randomly assigned to one of eight different treatment arms ${ }^{10}$ :

- Minimal Framing baseline: Participants could choose to take 0\%, 25\%, 50\%, 75\%, or $100 \%$ of their $\$ 500,000$ balance as a lump sum. They indicated their annuitization choice by clicking one of five buttons that were ordered from $0 \%$ cash-out on the far left to $100 \%$ cash-out on the far right. A horizontal axis with an arrow on each end was shown above the buttons. The left end of the axis was labeled "Lower lump sum/More guaranteed income" and the right end of the axis was labeled "Higher lump sum/Less guaranteed income." (See Figure 5.) The remaining treatments were identical to the Minimal Framing baseline except in the ways described below.

- All or Nothing treatment: Participants were only allowed to choose to annuitize their entire $\$ 500,000$ balance or receive a $\$ 500,000$ lump-sum payment. This treatment showed no horizontal axis.

- Good Deal treatment: This treatment was designed to overcome any reluctance to annuitize due to the fear of foregoing a better deal elsewhere. The following text was added to the description of the annuity: "The guaranteed lifetime income option gives you higher payments than you would get by buying an identical product from an insurance company because your employer will not charge you fees."

- Total Payments treatment: The motivation for this treatment was the hypothesis that the reluctance to annuitize may partly be due to the contrast between the large size of the lump sum and the small size of the monthly annuity payment. If this is the case, highlighting the undiscounted expected total payments from complete annuitization, which are larger than the $\$ 500,000$ lump sum amount, may increase annuitization. We added the text, "The average individual who chooses $100 \%$ guaranteed income will receive total lifetime payments of $\$ x$." The number $x$ was the expected undiscounted total lifetime payments of a $100 \%$ annuitization choice, which was $\$ 695,765$ for single participants and $\$ 775,382$ for married participants. 11

\footnotetext{
${ }^{10}$ One treatment we did not implement is making salient to respondents that Social Security provides a real annuity. We suspect that such a treatment would have reduced annuity demand, although we have no empirical evidence on this matter.

${ }^{11}$ We used the average of male and female mortality rates to calculate this expectation for singles, and assumed that married spouses were both 65 years old.
} 
- Investment Framing treatment: Brown et al. (2008) find that an investment frame discourages annuitization relative to a consumption frame. In this treatment, we included a discussion of how the rate of return would vary with longevity: "Under the guaranteed income option, you get a higher return on your $\$ 500,000$ investment if you die old and a lower return if you die young. Under the lump sum, you get the same return whether you die young or old." We relabeled the axis to show "Higher return if you die old/Lower return if you die young" on the left side, and "Same return whether you die young or old," on the right side. This frames the annuity as risky, rather than emphasizing its role in providing insurance.

- Flexibility and Control treatment: Annuities may be unattractive because they require giving up control of one's investments and the timing of one's spending. We added the following language about flexibility and control: "Choosing a bigger lump sum gives you more control over your investments and more flexibility over the timing of your spending." We changed the axis labels to "You have less control and less flexibility" on the left side and "You have more control and more flexibility" on the right side.

- Longevity Insurance treatment: The Investment Framing treatment framed annuities as a risky choice. The Longevity Insurance treatment framed annuities as a risk-reducing choice. We added the following text: "Choosing more guaranteed income gives you more assurance that you will not outlive your savings, since the monthly payments will continue as long as you live." We changed the axis labels to "Less risk of outliving your savings" on the left side and "Greater risk of outliving your savings" on the right side.

- Mortality Credits treatment: Reluctance to annuitize may be driven by a failure to realize that annuities have the attractive property of transferring money from low marginal utility states to high marginal utility states. We added the following language to explain this: "The monthly payment from the guaranteed lifetime income option is much higher than the interest you would receive from investing the lump sum. The guaranteed income option stops payments when you are no longer alive. In return, the guaranteed income option delivers very high pay-outs as long as you live. You are giving up payments when you are no longer alive (and don't need the money) and receiving extra-large payments as long as you are alive (and need the money)."

After making an annuitization choice, participants were shown a graph of the likelihood that a person aged 65 today would live to at least age 70,75, 80, 85, 90, 95, and 100. They were asked to again elect how to receive their pension payment, with the qualification that it was fine to give the same answer as the previous question. The purpose of this second elicitation was to see whether unrealistic longevity expectations were affecting the annuitization choice.

Participants in every treatment arm were then asked about a cost-of-living-adjustment provision. We presented the following scenario: "Now suppose that your employer only offers a guaranteed lifetime income option. But you can choose whether you want a cost-of- 
living adjustment (COLA) to your payments." Each participant was randomly assigned (independent of their assignment to the previous treatments) to one of three versions of the COLA question:

- Minimal Inflation Information baseline: Unmarried participants were told, "If you don't choose a cost-of-living adjustment, then your monthly pension payment will be $\$ 2,981$ a month for the rest of your life. If you do choose a cost-of-living adjustment, then your first monthly pension payment will be $\$ 2,033$ a month, but this amount will increase over time at a rate equal to the inflation rate (as measured by the Consumer Price Index)." Married participants had the two dollar figures replaced with $\$ 2,616$ and $\$ 1,784$. Participants were then asked whether they preferred a COLA over no COLA.

- Inflation Compounding treatment: Some people may not fully understand what inflation is. In addition, many people underestimate how quickly exponential series grow (Eisenstein and Hoch, 2005). Therefore, they may be unaware how much low levels of annual inflation will erode the purchasing power of a dollar over long horizons. In this treatment, we added to the Minimal Inflation Information baseline text a slightly fuller explanation of inflation and a calculation illustrating the longrun power of inflation. The following text was appended to the description of the no-COLA option for unmarried participants: "This means that as the cost of living increases, \$2,981 per month will buy fewer goods and services. For example, if the cost of living increases by $2 \%$ per year for the rest of your life and you don't have a cost-of-living adjustment, your monthly pension payment will buy $33 \%$ fewer goods and services at age 85 than it does at age 65." The text for married participants was analogous. The COLA option description had the following additional sentence: "So your monthly payment will buy about the same amount of goods and services at every age in the future as it does at age 65."

- Inflation Compounding With Graph treatment: This treatment was identical to the Inflation Compounding treatment, except we also included a graph of what nominal payments would be from age 65 to 100 for the annuity with and without the COLA.

We set the initial monthly payment amount for the annuity with a COLA in the above questions to be $68.2 \%$ of the non-COLA annuity's monthly payment. We computed this ratio using June 6, 2012 quotes from the Principal Life Insurance Company for a \$500,000 joint and $100 \%$ survivor annuity with and without an inflation adjustment based on changes in the Consumer Price Index for All-Urban Consumers (CPI-U). ${ }^{12}$

After answering the annuity choice questions, Survey 2 participants were asked to rate the importance on a six-point Likert scale ( 0 for not important, 5 for very important) of ten reasons for their lump sum versus annuity choices. These reasons mostly overlapped with those in Survey 1. Participants were also asked questions about their life expectancy,

${ }^{12}$ The annuity monthly payouts (obtained via the Hueler Income Solutions web site) were $\$ 2,232.42$ per month with no COLA and $\$ 1,524.44$ per month with a COLA, giving a ratio of $68.2 \%$. The CPI-U rider had no cap on the increase, and the monthly payment would be adjusted annually on the contract anniversary date. If the CPI-U were negative, the periodic benefit would not decrease. Future years' monthly payments would not increase until CPI-U exceeded its previous high. 
demographics, and the clarity of the survey that were identical to the Survey 1 questions. As with Survey 1, the vast majority (93\%) of Survey 2 participants reported that the questions were understandable and clear, and less than $1 \%$ found the survey to be "mostly confusing" or "completely confusing" (Table 1).

\section{Summary statistics}

Table 2 presents summary statistics on participant demographics and relative life expectancy in Surveys 1 and 2. The two survey populations are very similar. ${ }^{13}$ The mean age is 59.5 years for Survey 1 and 59.6 years for Survey 2. In both surveys, 50\% of participants are male, $55 \%$ are married, and the average number of children is 2. Somewhat more Survey 2 respondents are retired than Survey 1 respondents: $40 \%$ versus $36 \%$. Almost $40 \%$ of participants have a DB pension, and about $70 \%$ own a home. The median net worth for participants, which we measure with considerable noise and for only about three-quarters of our sample, is $\$ 162,500$ in Survey 1 and $\$ 150,000$ in Survey 2, and the respective means are $\$ 298,217$ and $\$ 286,594 .{ }^{14}$ College graduates comprise about $40 \%$ of both samples, and 12 to $13 \%$ of the sample have a post-graduate degree.

We asked respondents how much longer they expected to live relative to others their age. In Survey $1,36 \%$ of participants said they expected to live longer than the average person their age, 54\% said they expected to live about the same amount of time as the average person their age, and $10 \%$ said they expected to die sooner than the average person their age. Responses to Survey 2 were similar: $34 \%$ of participants anticipated a relatively long life, $54 \%$ anticipated a life about as long as that of an average person of the same age, and $12 \%$ anticipated a relatively short life. The greater number of people anticipating a relatively long life is not necessarily evidence of optimistic bias, since our sample is more educated than the typical American in this age bracket, and longevity is positively correlated with education (Meara, Richard, and Cutler, 2008). The U.S. Census reports that among all 45 to 64 year olds in the U.S. in 2007, only $29 \%$ were college graduates.

Consistent with the importance of adverse selection in annuity markets, the average percent of balances annuitized was significantly lower for respondents with lower self-reported life expectancy. Averaging the five lump sum versus annuity decisions in the two surveys, those who expected to die sooner annuitized $47 \%$ of their balances, those who expected to live about the average length annuitized 56\%, and those who expected to live longer than average annuitized 57\% (not shown in tables). The difference between the lowest life expectancy group and the others is significant at the $1 \%$ level.

\section{Results}

We present six sets of findings: 1) demographic correlates of annuitization, 2) obstacles to and motivations for annuitization, 3) the effect of offering partial annuitization, 4) the

\footnotetext{
${ }^{13}$ There is no overlap in the individuals included in Survey 1 and Survey 2.

${ }^{14}$ Out of the 1,000 participants in Survey 1 and 4,130 participants in Survey 2, there were 752 and 3,169, respectively, who responded to all of the questions necessary to calculate net worth. The surveys had participants give interval responses for the components of net worth. To calculate total net worth, we map each interval to its midpoint except in the case of intervals without an upper bound, which we map to a value equal to $150 \%$ of the lower bound of the upper interval.
} 
desired intertemporal slope of retirement income and the demand for COLAs, 5) framing effects, and 6) the demand for "bonuses" (uneven intra-year payments).

\section{A. Demographic correlates of annuitization}

Table 3 shows the results of regressing the fraction of balances annuitized in each of the five annuity versus lump sum decisions in our surveys on age, number of children, and dummies for being male, a college graduate, married, retired, and a homeowner. In Survey 1, the three decisions involved tradeoffs between the lump sum and the Steady Income, Match-Inflation, or High-Growth annuity. In Survey 2, the two decisions involved tradeoffs between the flat nominal annuity and the lump sum before seeing the mortality graph and after seeing the mortality graph. We pool all of the treatment arms in each Survey 2 regression.

We find that collectively, the demographic variables explain very little of the variation in annuitization choices (the $\mathrm{R}^{2} \mathrm{~s}$ are all very low); in addition, very few of the demographic variables are significantly correlated with annuity demand. In Survey 1, being a homeowner is associated with a 5.8 percentage point lower fraction of balances invested in the Steady Income annuity. In Survey 2, being married is associated with a 3.9 percentage point higher fraction of balances invested in the flat nominal annuity before seeing the mortality graph. After seeing the mortality graph, being retired is associated with a 3.0 percentage point higher fraction of balances annuitized, and each child is associated with a 0.7 percentage point lower fraction of balances annuitized. In untabulated results, we additionally control for net worth, which reduces our sample sizes because of non-response. Net worth is negatively correlated with the fraction invested in the Steady Income annuity in Survey 1. This additional control also causes the homeowner dummy to lose significance in the Steady Income regression and the number of children variable to lose significance in the Survey 2 regression of annuitization percentage after seeing the mortality chart.

It is difficult to compare these results to others in the literature on the demographic correlates of annuitization because the hypothetical situations in which our respondents made their decisions differ from the real or hypothetical situations in which individuals in other studies made their annuitization decisions. In addition, other studies control for a different set of covariates than we do, so the coefficient on a given variable has a different interpretation in our analysis than in others. Brown (2001) finds that among older U.S. adults in the Health and Retirement Survey, self-reported intentions to annuitize DC plan assets in the future are higher for single individuals and those with less wealth, but do not vary with current age, gender, education, and the presence of children when a modelestimated value of annuitizing is controlled for. Mottola and Utkus (2007) examine actual annuitization choices at two large U.S. firms and report that lower wealth, female gender, and being unmarried are associated with more annuitization. ${ }^{15}$

${ }^{15}$ For evidence on demographic correlates of annuity demand outside the U.S., see Bütler and Teppa (2007) and Inkmann, Lopes, and Michaelides (2011). 


\section{B. Obstacles to and motivations for annuitization}

In Figure 6, we present the average importance individuals reported placing on various factors when making their lump sum versus annuitization choices. Ratings are similar across the two surveys on factors whose importance rating was elicited on both surveys. The factor with the highest average importance is the desire to "make sure I have enough income later in life," with an average rating of 3.9 to 4.0 out of 5 . The next highest category is "flexibility in the timing of my spending," with an average rating of 3.5 in both surveys, closely followed by "worried about company not being able to pay me," with an average rating of 3.4 in both surveys. The desire for flexibility manifests itself in the 3.2 rating placed on "I might have a big spending need sometime during retirement" (asked only on Survey 2). The low rating of 1.6 on "I have a big spending need right after retirement" (asked only on Survey 1) suggests that respondents do not have a specific spending need in mind.

Worries about inflation (average rating of 3.0 to 3.3), the desire to invest the money on one's own (average rating of 3.0 to 3.1), and the desire to prevent overspending (average rating of 2.7 to 3.0) are intermediate-level concerns. In contrast, two other motives that are commonly discussed in the annuities literature are reported to have little absolute importance by our survey participants. The desire to give money to children or others garners an average rating of 2.1 to 2.4 , and worries about dying early receive an average rating of 2.3. The factor rated least important is the desire to keep money away from children or others, which has an average rating of 1.4. In Survey 1, the annuity offered did not have a survivor benefit, and the fact that lifetime payments would not provide for one's spouse after one's death has a 3.5 importance rating among married participants in this survey.

How do these factor ratings correlate with annuitization choices? Table 4 shows results from regressing the percent of balances subjects choose to annuitize in Survey 2 before seeing the mortality chart on the subjects' factor ratings, pooling together all the treatment arms. ${ }^{16} \mathrm{All}$ of the factor ratings except "want to keep money from children or others" (which had the lowest absolute importance rating in Survey 2) and "I might have a big spending need sometime during retirement" are significantly correlated with the fraction of balances annuitized. Annuitization is increasing in the importance placed on having enough income later in life, worries about inflation, and the desire to prevent overspending, while it is decreasing in the importance placed on flexibility in the timing of spending, worries about counterparty risk, the desire to invest money on one's own, the desire to give money to one's children or others, and worries about dying early. The insignificance of "I might have a big spending need sometime during retirement" is initially puzzling given that factor's high absolute importance rating, but the factor's coefficient becomes negative and significant if the "Want flexibility in the timing of my spending" rating is excluded from the regression, indicating that the former rating captures a strict subset of the motives measured by the latter rating.

${ }^{16}$ The regression results from using Survey 1 annuity choices are broadly similar. Additionally controlling for Survey 2 treatment dummies and demographic characteristics does not qualitatively alter the coefficients on the factor importance ratings. 
From the perspective of product design, it is not obvious whether the levels (Figure 6) or the sensitivities (Table 4) are the most relevant statistics. In Appendix 2, we sketch a model that analyzes this issue (without resolving it one way or the other).

\section{Partial annuitization}

Mark Iwry, senior adviser to the Secretary of the Treasury and deputy assistant secretary for retirement and health policy, has stated that the U.S. Treasury Department would like to see DB plans move away from offering an "all-or-nothing" choice between an annuity and a lump sum to offering a variety of choices combining annuity and lump-sum payouts (Steverman, 2012). To assess the effect of such a change, we compare annuitization choices under two treatments in Survey 2: i) the All or Nothing treatment, in which the only options were 0\% Annuitization and 100\% annuitization, and ii) the Minimal Framing baseline which contained five annuitization options (from $0 \%$ to $100 \%$ in increments of $25 \%$ ).

Figure 7 shows the distribution of annuitization percentages chosen under each condition prior to seeing the mortality chart. We find that a majority of individuals (59\%) choose partial annuitization when given the opportunity to do so. These partial annuitants represent shifts from both the full annuitization and full lump-sum outcomes under the All or Nothing treatment. The fraction of individuals who fully annuitize falls from $50 \%$ to $21 \%$, and the fraction of individuals who choose a full lump sum similarly falls from $50 \%$ to $20 \%$. Correspondingly, allowing for partial annuitization increases the fraction of people choosing a positive amount of annuitization from $50 \%$ to $80 \%$. Finally, allowing partial annuitization raises the average percent of pension wealth annuitized from 50\% to 57\%. These last two differences are significant at the $1 \%$ level and do not qualitatively change if we additionally control for age, gender, having a college degree, marital status, retirement status, number of children, and home ownership (regression results in Online Appendix Table A2). Our findings suggest that expanding the use of partial annuitization in DB settings where total cash-outs are already allowed might lead to higher annuitization rates. ${ }^{17}$

\section{Slopes of annuity payments and COLAs}

Our surveys measured subjects' preferences with respect to the slope of the annuity payout stream. Recall that Survey 1 respondents made binary choices between payments of identical present value that decline $2 \%$ per year, stay flat, or increase $2 \%$ per year in real terms. Figure 8 shows that among respondents with single-peaked preferences over payout streams, ${ }^{18} 19 \%$ preferred the declining real annuity (-2\% per year), $32 \%$ preferred the flat real annuity, and $50 \%$ preferred the rising real annuity $\left(+2 \%\right.$ per year). ${ }^{19}$ In other words, our

\footnotetext{
${ }^{17}$ Using data on annuitization choices in Swiss defined-benefit plans, Bütler and Teppa (2007) find that most people choose $0 \%$ or $100 \%$ annuitization even when partial annuitization is an option. This could be due to workers being unaware of the partial annuitization option and/or communications materials focusing on all or nothing (rather than partial) annuitization options. ${ }^{18}$ By this, we mean excluding the $11 \%$ who both chose real payments that decline $2 \%$ per year over flat real payments and real payments that increase $2 \%$ per year over flat real payments.

${ }^{19}$ When we regress a dummy for choosing a declining real annuity on Survey 1 participants' ratings of the importance of various factors in their lump sum versus annuitization choice, we find that a one standard deviation increase in worry about the company not being able to pay in the future is associated with a 3.4\% higher likelihood of choosing the declining annuity, a one standard deviation increase in worry about inflation is associated with a 5.6\% lower likelihood of choosing the declining annuity, and a one standard deviation increase in concern that the lifetime payments would not provide for one's spouse is associated with a $3.1 \%$ lower likelihood of choosing the declining annuity. The other measured motives have no significant correlation with choosing the declining annuity.
} 
respondents overwhelmingly preferred flat or rising real retirement payment paths rather than falling real paths, holding the present value of the payments fixed. ${ }^{20}$

By comparison, Hurd and Rohwedder (2011) find that, holding household composition fixed, real consumption declines by about $2 \%$ per year during retirement. How can we reconcile our survey respondents' reported preference for rising payments with the declining actual consumption streams of retired households? Several complementary explanations are plausible.

First, annuities enable agents to shift resources from death states to survival states. This has the effect of lowering the implied rate of return in death states (when the value of the annuity is lost) and raising the implied rate of return in survival states (since the annuitant receives the normal market rate of return plus an implicit survivorship bonus, a transfer from the decedents in the annuity pool). Because of this state-dependent rate of return, an agent with access to an annuity should choose a higher rate of consumption growth relative to an agent without access to an annuity. The Appendix contains a formal (Euler equation) derivation of this familiar result. If individuals in the real world do not have access to fairly priced annuities while those in the survey do, this could potentially reconcile the different patterns.

Second, households may have biased expectations. For example, households may underestimate the frequency of transitory spending needs, such as home repairs, out-ofpocket healthcare expenses, etc. This will cause them to spend more than the annuity value of their wealth, resulting in a realized consumption path that declines over time due to the budget constraint despite their preference for a rising path. Households may be overly optimistic about their asset returns, which would also cause their realized consumption path to decline faster than they expected. Households may not anticipate the extent to which consumption and health status are complements (Finkelstein, Luttmer, and Notowidigdo, 2012), causing them to believe they will want to spend more in advanced old age than they actually do.

Third, Survey 1 respondents may believe their life expectancy to be longer than the life expectancy that equates the present value of the various payment streams. Such a belief would lead them to expect to collect a greater present value of payments from the rising annuity than from the other two annuities. The greater perceived present value of the rising annuity could then cause respondents to choose it despite otherwise preferring a downwardsloping consumption path.

Fourth, households may have money illusion and set their early retirement spending at a level that allows them to sustain a flat nominal spending trajectory, not fully appreciating that a flat nominal path is a real path that falls at the rate of inflation. We leave a fuller discussion of money illusion in the annuity market to future work.

\footnotetext{
20 However, the percent of balances annuitized rather than cashed out is not very responsive to the annuity's payout slope, averaging $61.4 \%, 60.4 \%$, and $62.5 \%$ for the decreasing, flat, and increasing annuities, respectively. Only the difference between the flat and increasing annuities is significant at the $5 \%$ level.
} 
In practice, annuity and pension payouts change over time through cost of living adjustments (COLAs). Note that a typical COLA has two features: it changes the expected slope of payouts, and it provides a hedge against surprise inflation. While in principle these two features could be separated, they are in fact almost always bundled together. The prevalence of inflation-adjusted payouts differs dramatically across institutions. Contractual COLAs of some sort are almost universal in state and local government DB pension plans (Novy-Marx and Rauh, 2011). In private DB plans, contractual COLAs are relatively rare; these plans tend to instead have either ad-hoc adjustments (occasional and less than the inflation rate) or no adjustments (Allen, Clark, and Sumner, 1984, 1986a, 1986b). The vast majority of single-premium immediate annuities (SPIAs) purchased are not indexed to inflation.

In Survey 2, we asked respondents whether they wanted to add a COLA to their annuity. Doing so led to an initial monthly payment that was $32 \%$ lower than the no-COLA monthly payment. When this question was asked in the Minimal Inflation Information condition, $44 \%$ of participants chose the COLA. Adding a short description of inflation and explaining how much $2 \%$ annual inflation erodes purchasing power over two decades in the Inflation Compounding treatment raised the demand for a COLA from $44 \%$ to $67 \%$ (see Figure 9), a 23 percentage point increase that is significant at the $1 \%$ level. $^{21}$ This result suggests that an insufficient awareness of inflation's effects might depress the demand for COLAs in pension and annuity settings, and that enhancing the information about inflation's impact that is provided to retirees could substantially raise COLA take-up rates.

\section{E. Framing}

How do alternative frames influence annuitization choices? Figure 10 shows the distribution of annuitization choices made by respondents in the main framing treatments of Survey 2.

We examine the impact of these framing treatments on two outcomes: whether respondents chose to annuitize any balances before seeing the mortality graph, and the fraction of balances annuitized. The key explanatory variables in the regressions are six framing treatment dummies (the Minimal Framing treatment is the excluded category); the regressions also include a set of demographic controls. ${ }^{22}$

The first column of Table 5 reports the results from a linear probability regression where the dependent variable is a dummy for the respondent annuitizing a positive amount. The only framing treatment effect that is significant at conventional levels is that of the Flexibility and Control treatment, which told participants, "Choosing a bigger lump sum gives you more control over your investments and more flexibility over the timing of your spending." This treatment decreased the probability of annuitizing any balances by 7.8 percentage points relative to the Minimal Framing baseline (significant at the $1 \%$ level). The Investment Framing treatment—which told participants that the annuity's return would be high if they

\footnotetext{
${ }^{21}$ We also administered the Inflation Compounding With Graph treatment, which included a graph showing nominal annuity payments by age. We find that $62 \%$ of participants chose the COLA, a fraction that is significantly higher (at the $1 \%$ level) than the COLA take-up rate in the Minimal Inflation Information condition but significantly lower (at the $1 \%$ level) than the COLA take-up rate in the Inflation Compounding treatment (without a graph). It is possible that the nominal payments graph was a visual distraction that made participants less attentive to the text explaining inflation, but there are several alternative potential interpretations.

${ }^{22}$ The All or Nothing treatment recipients are excluded from the regression sample.
} 
died old and low if they died young, whereas the lump sum would give them the same return regardless of longevity - reduced the probability of any annuitization by 4.8 percentage points, an effect that is marginally significant at the $10 \%$ level.

The second column of Table 5 reports results from a regression whose dependent variable is the fraction of balances annuitized. Both the Flexibility and Control and Investment Framing treatments decreased the level of annuitization relative to the Minimal Framing baseline at the $1 \%$ significance level; those in the Flexibility and Control treatment have an 8.7 percentage point lower level of annuitization, while those in the Investment Framing treatment have a 6.0 percentage point lower level of annuitization.

Brown et al. (2008) find that an investment frame discourages annuitization relative to a consumption frame, but Brown, Kapteyn, and Mitchell (2012) do not find an investment framing effect in the context of Social Security claiming age. Our results fall in the middle, finding a negative effect of investment framing that is significant but smaller in magnitude than the results of Brown et al. (2008).

The remaining four framing treatments shown in Table 5 have coefficients that are generally of the anticipated positive sign (all of them in the first regression and all but one in the second regression), but these coefficients are closer to zero and not statistically significant. These null effects cast some doubt on the hypotheses that motivated these treatments: that annuity demand is suppressed by the fear of foregoing a better deal elsewhere, by the large contrast between the magnitude of the lump sum and the magnitude of the monthly annuity payment, by the failure to recognize the longevity insurance embedded in an annuity, or by the failure to recognize the attractive state-contingent payment properties of an annuity.

As a final framing experiment, we asked Survey 2 participants to make their annuitization choice again after seeing a graph of the probabilities of surviving to different ages, conditional on living to age 65 . Figure 11 shows the average annuitization rates for participants before and after seeing this mortality chart. The average annuitization rate in every experimental condition is lower after seeing the mortality graph; the percent of balances annuitized across all conditions drops from $55.4 \%$ to $52.2 \%$, a difference that is significant at the $1 \%$ level. The systematic drop could indicate that our respondents were on average over-optimistic about their expected relative longevity, and the mortality chart mitigated some of this bias, reducing annuity demand. ${ }^{23}$

\section{F. Annuities with "bonuses"}

Survey participants cited the desire for "flexibility in the timing of my spending" as one of the most important factors in their annuitization decision. Our ex ante expectation that this consideration would be important motivated exploring the demand for an annuity that offered a higher "bonus" payment in one month of each year, funded by lower payments in the remaining months. We find that $60 \%$ of Survey 1 respondents preferred a MatchInflation Income with Bonuses annuity over a Match-Inflation Income annuity without a

\footnotetext{
${ }^{23}$ There is a vast empirical literature on how subjective survival expectations relate to objective survival expectations. See, for example, Hamermesh (1985), Hurd and McGarry (1995), Hurd, McFadden, and Merrill (2001), Smith, Taylor, and Sloan (2001), Smith et al. (2001), Hurd and McGarry (2002), Gan, Hurd, and McFadden (2005), and Ludwig and Zimper (2012).
} 
bonus. Among those choosing the bonus, $58 \%$ wanted the bonus to be paid during the winter holiday season-November, December, and January (see Figure 12). However, our explanation of the bonus used "the December holiday season" as an example of when a bonus might be received, so some of the concentration in these months could be due to the explanation itself. Another caveat to keep in mind is that we did not measure the willingness to pay for this bonus feature, so we do not know the strength of the preference for bonuses.

The Match-Inflation Income with Travel Bonuses annuity proved to be less popular, although it still appealed to a significant fraction of the population. Forty-five percent of respondents preferred the Match-Inflation Income with Travel Bonuses annuity over the Match-Inflation annuity without bonuses. The lesser appeal of the travel bonuses may be due to the fact that they are paid in June; the fact that their size declines with each decade of life, creating an overall declining real path for yearly annuity payments; and/or the fact that they make salient respondents' physical decline in old age. Our previously discussed results showed that people usually prefer their bonuses to be paid in November, December, or January and that people dislike downward-sloping real payment paths.

\section{Conclusion}

In this paper, we analyzed two large surveys of hypothetical annuitization choices to learn what motives are important in annuitization choices and whether annuity product design and framing of the annuity choice can significantly affect annuity demand. Although hypothetical choices must be interpreted with caution, since they may not closely correspond to the choices people would actually make, they allow us to measure preferences for products not currently available in the market and examine choices in economic environments that differ from the current one. Surveys like ours provide a starting point for designing field experiments that involve actual consequential choices.

Our results have several implications for annuity product design and choice architecture. To increase annuity demand, annuity providers could design products that give beneficiaries more flexibility and control. Our bonus annuity is an example of personalization that increases flexibility and control without compromising longevity insurance. Another example is an annuity with multiple annual bonuses. Such bonuses could either be preselected at the time the annuity was purchased or selected at the beginning of each calendar year. In fact, the payout stream for a given year could be made completely flexible without creating a substantial adverse selection problem. Problematic adverse selection would only arise if inter-year reallocations were allowed, so that a beneficiary could drain his entire annuity following a significant adverse health event.

Other forms of personalization and flexibility could also be adopted, such as limited penaltyfree early withdrawals and even asset allocation flexibility (adopting some features of the variable annuity market). Of course, there is a tradeoff between greater flexibility/control and greater complexity. Too much flexibility may drive some consumers away from annuities (cf. Ivengar and Kamenica, 2010). Finding the optimal mix of flexibility and simplification is a significant challenge. 
We also find that most consumers prefer partial annuitization of their retirement nest egg over either $0 \%$ or $100 \%$ annuitization. We find that the availability of partial annuitization raises the average fraction of wealth that ends up annuitized.

Framing changes may also increase the appeal of annuities, especially frames that make the option of partial annuitization salient. In addition, frames that downplay investment attributes of annuities may increase annuitization rates. Regarding choices about COLAs, discussing the implications of inflation for purchasing power over long horizons increases demand for rising nominal payment paths.

Finally, participants report that fears of counterparty risk play a large role in their annuitization choices. By adopting regulations that reduce this fear, policy makers may create moral hazard problems from consumers disregarding the financial stability of annuity providers, but they may also increase overall demand for annuities.

\section{Supplementary Material}

Refer to Web version on PubMed Central for supplementary material.

\section{Acknowledgments}

We thank Christine Polek, Michael Puempel, and Gwendolyn Reynolds for excellent research assistance, and David John, Josh Rauh, Karl Scholz, Annette Vissing-Jorgenson, and participants at the Aspen Conference on Economic Decision Making, the NBER Jackson Hole Conference on State and Local Pensions, the ASSA annual meetings, the Bank of Israel Research Department, Columbia Business School, the RAND Behavioral Finance Forum, the Urban Institute, TIAA-CREF Institute research symposia, the University of Michigan and George Washington University for helpful comments and suggestions. This research was supported by the U.S. Social Security Administration through grants to the RAND / Dartmouth / Wharton Financial Literacy Center and the National Bureau of Economic Research as part of the SSA Retirement Research Consortium (grants FLR09010202-02 and \#5 RRC08098400-04-00), the TIAA-CREF Institute, and the National Institutes of Health (grants P01-AG005842, P30-AG034532, and R01-AG021650). The findings and conclusions expressed are solely those of the authors and do not represent the views of SSA, any agency of the Federal Government, or the NBER. The authors have, at various times in the last three years, been compensated to present academic research at events hosted by financial institutions that administer retirement savings plans and/or provide annuities. See the authors' websites for a complete list of outside activities.

\section{References}

Agnew, Julie; Anderson, Lisa; Gerlach, Jeffrey; Szykman, Lisa. Who Chooses Annuities? An Experimental Investigation of the Role of Gender, Framing and Defaults. American Economic Review. 2008; 98(2):418-422.

Allen, Steve; Clark, Robert; Sumner, Daniel. A Comparison of Pension Benefit Increases and Inflation, 1973-79. Monthly Labor Review. 1984; 107(5):42-46.

Allen, Steve; Clark, Robert; Sumner, Daniel. Post-Retirement Adjustments of Pensions. Journal of Human Resources. 1986a; 21(1):118-137.

Allen, Steve; Clark, Robert; Sumner, Daniel. Inflation and Pension Benefits. In: Ippolito, Richard; Kolodrubetz, Walter, editors. The Handbook of Pension Statistics 1985. Chicago: Commerce Clearing House; 1986b. p. 177-250.

Ameriks, John; Caplin, Andrew; Laufer, Steven; Nieuwerburgh, Stijn Van. The Joy of Giving or Assisted Living? Using Strategic Surveys to Separate Public Care Aversion from Bequest Motives. The Journal of Finance. 2011; 66(2):519-561.

Aon Hewitt. [Accessed August 2012] Global Pension Risk Survey 2011: US Survey Findings. 2011. http://www.aon.com/attachments/thought-leadership/2011prmsurvey_sponsor_final.pdf 
Banerjee, Sudipto. Annuity and Lump-Sum Decisions in Defined Benefit Plans: The Role of Plan Rules. EBRI working paper. 2013

Benartzi, Shlomo; Previtero, Alessandro; Thaler, Richard H. Annuity Puzzles. Journal of Economic Perspectives. 2011; 25.4:143-64.

Bernheim, B Douglas. How Strong Are Bequest Motives? Evidence on Estimates of Demand for Life Insurance and Annuities. Journal of Political Economy. 1991; 99:899-927.

Beshears, John; Choi, James; Laibson, David; Madrian, Brigitte. Behavioral Economics Perspectives on Public Sector Pension Plans. Journal of Pension Economics and Finance. 2011; 10(2):315-336. [PubMed: 21789032]

Brown, Jeffrey R. Private Pensions, Mortality Risk, and the Decision to Annuitize. Journal of Public Economics. 2001; 82:29-62.

Brown, Jeffrey R. Understanding the Role of Annuities in Retirement Planning. In: Lusardi, Annamaria, editor. Overcoming the Saving Slump: How to Increase the Effectiveness of Financial Education and Saving Programs. Chicago: University of Chicago Press; 2008.

Brown, Jeffrey R.; Kapteyn, Arie; Mitchell, Olivia S. Framing and Claiming: How InformationFraming Affects Expected Social Security Claiming Behavior. unpublished manuscript. 2012

Brown, Jeffrey R.; Kling, Jeffrey R.; Mullainathan, Sendhil; Wrobel, Marian V. Why Don't People Insure Late-Life Consumption? A Framing Explanation of the Under-Annuitization Puzzle. American Economic Review. 2008; 98(2):304-309.

Bütler, Monika; Peijnenburg, Kim; Staubli, Stefan. How Much Do Means-Tested Benefits Reduce the Demand for Annuities? CESifo Working Paper 3493. 2011

Bütler, Monika; Teppa, Federica. The Choice Between an Annuity and a Lump Sum: Results From Swiss Pension Funds. Journal of Public Economics. 2007; 91:1944-1966.

Chalmers, John; Reuter, Jonathan. How do Retirees Value Life Annuities? Evidence From Public Employees. Review of Financial Studies. 2012; 25(8):2601-2634.

Davidoff, Thomas; Brown, Jeffrey; Diamond, Peter. Annuities and Individual Welfare. American Economic Review. 2005; 95(5):1573-1590.

Dushi, Irena; Webb, Anthony. Household Annuitization Decisions: Simulations and Empirical Analyses. Journal of Pension Economics and Finance. 2004; 3:109-143.

Eisenstein, Eric; Hoch, Stephen. Manuscript. Temple University; 2005. Intuitive Compounding: Framing, Temporal Perspective, and Expertise.

Federal Register. Proposed Rules. 2012; 77, No 23 2/3/2012 http://www.gpo.gov/fdsys/pkg/ FR-2012-02-03/pdf/2012-2341.pdf.

Finkelstein, Amy; Poterba, James. Adverse Selection in Insurance Markets: Policyholder Evidence from the U.K. Annuity Market. Journal of Political Economy. 2004; 112(1):183-208.

Finkelstein, Amy; Luttmer, Erzo FP.; Notowidigdo, Matthew J. What Good is Wealth Without Health? The Effect of Health on the Marginal Utility of Consumption. Journal of the European Economic Association. 2012 forthcoming.

Fitzpatrick, Maria. How Much Do Public School Teachers Value Their Retirement Benefits?. Working Paper. 2012. http://www.human.cornell.edu/pam/people/upload/Fitzpatrick-Pensions-120117.pdf

Friedman, Benjamin M.; Warshawksy, Mark J. The Cost of Annuities: Implications for Savings Behavior and Bequests. Quarterly Journal of Economics. 1990; 105:135-54.

Gan, Li; Hurd, Michael D.; McFadden, Daniel. Individual Subjective Survival Curves. In: Wise, David, editor. Analyses in the Economics of Aging. Chicago, IL: University of Chicago Press; 2005. p. 377-411.

Hamermesh, Daniel S. Expectations, Life Expectancy, and Economic Behavior. Quarterly Journal of Economics. 1985; 100:389-408.

Hurd, Michael D.; McFadden, Daniel; Merrill, Angela. Predictors of Mortality Among the Elderly. In: Wise, David, editor. Themes in the Economics of Aging. Chicago, IL: University of Chicago Press; 2001. p. 171-198.

Hurd, Michael D.; McGarry, Kathleen. Evaluation of the Subjective Probabilities of Survival in the Health and Retirement Study. Journal of Human Resources. 1995; 30:S268-S292. 
Hurd, Michael D.; McGarry, Kathleen. The Predictive Validity of Subjective Probabilities of Survival. Economic Journal. 2002; 112:966-985.

Hurd, Michael D.; Rohwedder, Susann. Economic Preparation for Retirement. In: Wise, David A., editor. Investigations in the Economics of Aging. National Bureau of Economic Research; 2011. p. 77-113.

Inkmann, Joachim; Lopes, Paula; Michaelides, Alexander. How Deep is the Annuity Market Participation Puzzle? Review of Financial Studies. 2011; 24(1):279-319.

Ivengar SS, Kamenica E. Choice Proliferation, Simplicity Seeking, and Asset Allocation. Journal of Public Economics. 2010; 94(7-8):530-539.

Johnson, Richard W.; Burman, Leonard E.; Kobes, Deborah I. Annuitized Wealth at Older Ages: Evidence from the Health and Retirement Study. Washington DC: The Urban Institute; 2004.

Lockwood, Lee. Bequest Motives and the Annuity Puzzle. Review of Economic Dynamics. 2012; 15(2):226-243. [PubMed: 22822300]

Ludwig, Alexander; Zimper, Alexander. A Parsimonious Model of Subjective Life Expectancy. University of Cologne working paper. 2012

Meara, Ellen R.; Richard, Seth; Cutler, David. The Gap Gets Bigger: Changes in Mortality and Life Expectancy, by Education, 1981-2000. Health Affairs. 2008; 27(2):350-360. [PubMed: 18332489]

Mitchell, Olivia; Poterba, James; Warshawsky, Mark J.; Brown, Jeffrey R. New Evidence on the Money's Worth of Individual Annuities. American Economic Review. 1999; 89:1299-1318.

Modigliani, Franco. Life Cycle, Individual Thrift, and the Wealth of Nations. American Economic Review. 1986; 76(3):297-313.

Mottola, Gary; Utkus, Stephen P. Lump Sum or Annuity? An Analysis of Choice in DB Pension Payouts. Vanguard Center for Retirement Research. 2007; 30

Novy-Marx, Robert; Rauh, Joshua. Public Pension Promises: How Big Are They and What Are They Worth? The Journal of Finance. 2011; 66(4):1211-1249.

Pang, Gaobo; Warshawsky, Mark. Optimizing the Equity-Bond-Annuity Porfolio in Retirement: The Impact of Uncertain Health Expenses. Insurance: Mathematics and Economics. 2010; 46:198-209.

Pashchenko, Svetlana. Accounting for non-annuitization. Federal Reserve Bank of Chicago Working Paper WP-2010-03. 2010

Poterba, James; Venti, Steven; Wise, David. Journal of Economic Perspectives. Vol. 25. American Economic Association; 2011. The Composition and Drawdown of Wealth in Retirement; $p$. 95-118.Fall

Previtero, Alessandro. Manuscript. University of Western Ontario; 2012. Driving by Looking in the Rearview Mirror: Stock Returns and Annuitization and Older Ages.

Smith, V Kerry; Taylor, Donald H.; Sloan, Frank A. Longevity Expectations and Death: Can People Predict Their Own Demise? American Economic Review. 2001; 91:1126-1134.

Smith, V Kerry; Taylor, Donald H.; Sloan, Frank A.; Johnson, F Reed; Desvouges, William H. Do Smokers Respond to Health Shocks? Review of Economics and Statistics. 2001; 83:675-687.

Steverman, Ben. [Accessed August 2012] Mark Iwry: Bringing Annuities to 401(k)s. Bloomberg Businessweek. 2012. http://www.businessweek.com/news/2012-04-17/mark-iwry-bringingannuities-to-401-k-s

Warner, John; Pleeter, Saul. The Personal Discount Rate: Evidence from Military Downsizing Programs. American Economic Review. 2001; 9112:33-53.

Yaari, Menahem. Uncertain Lifetime, Life Insurance, and the Theory of the Consumer. The Review of Economic Studies. 1965; 32(2):137-150. 


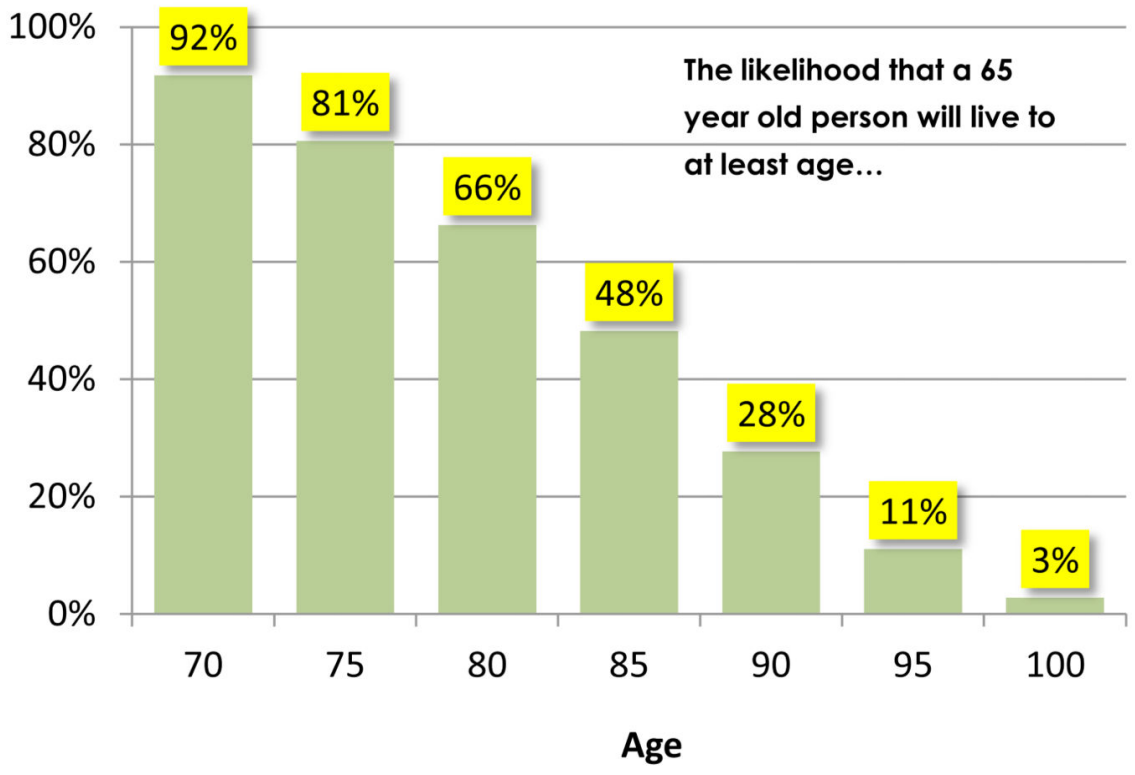

Figure 1. Mortality graph in Survey 1 


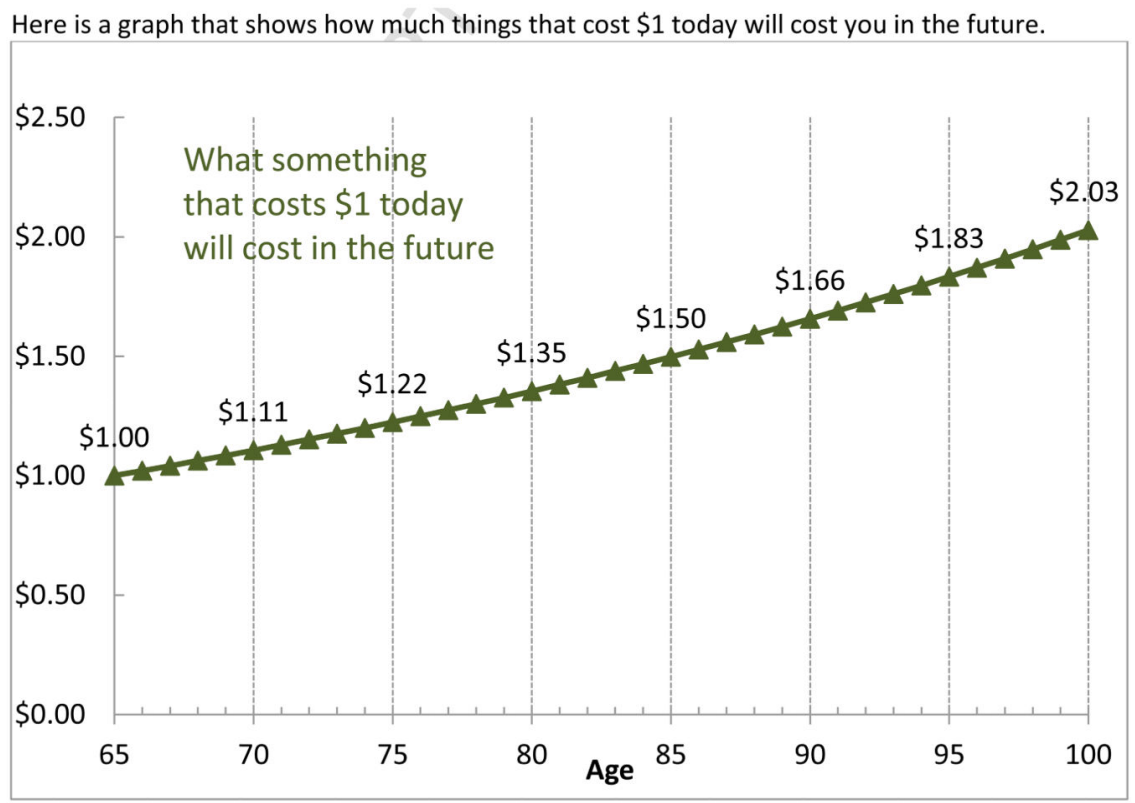

Figure 2. Inflation graph in Survey 1 


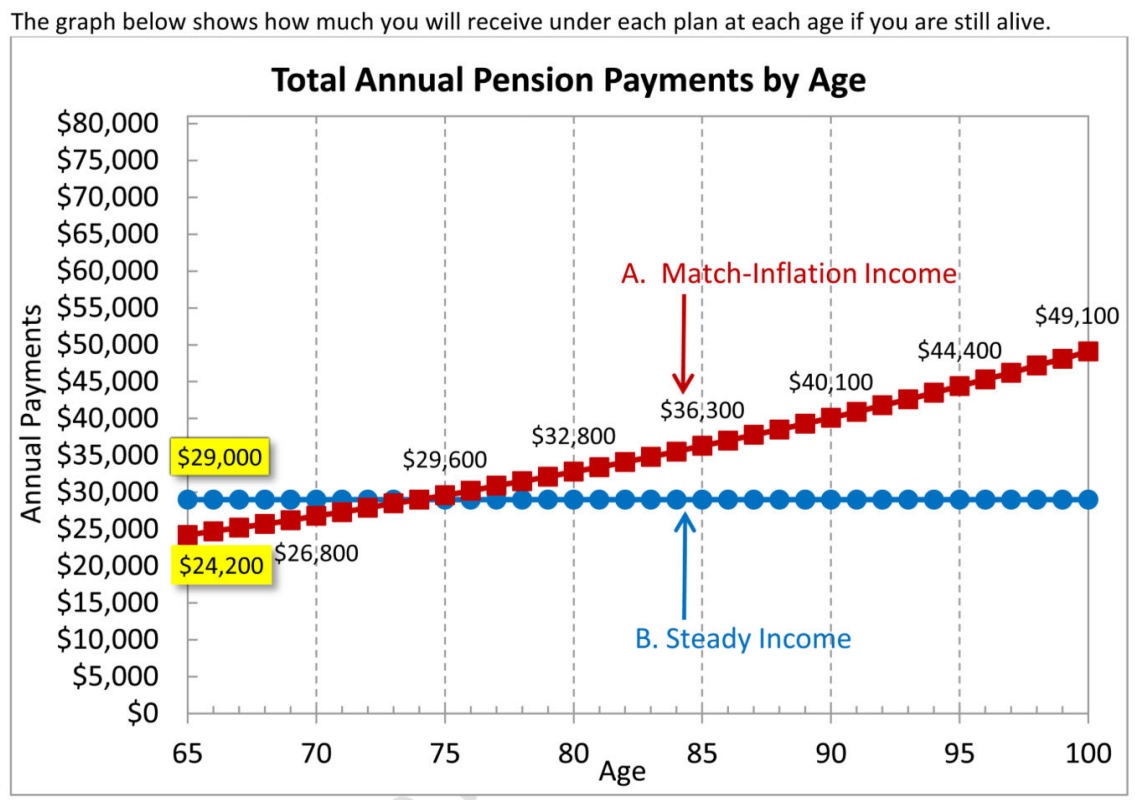

Figure 3. Match Inflation vs. Steady Income nominal payment graph in Survey 1 


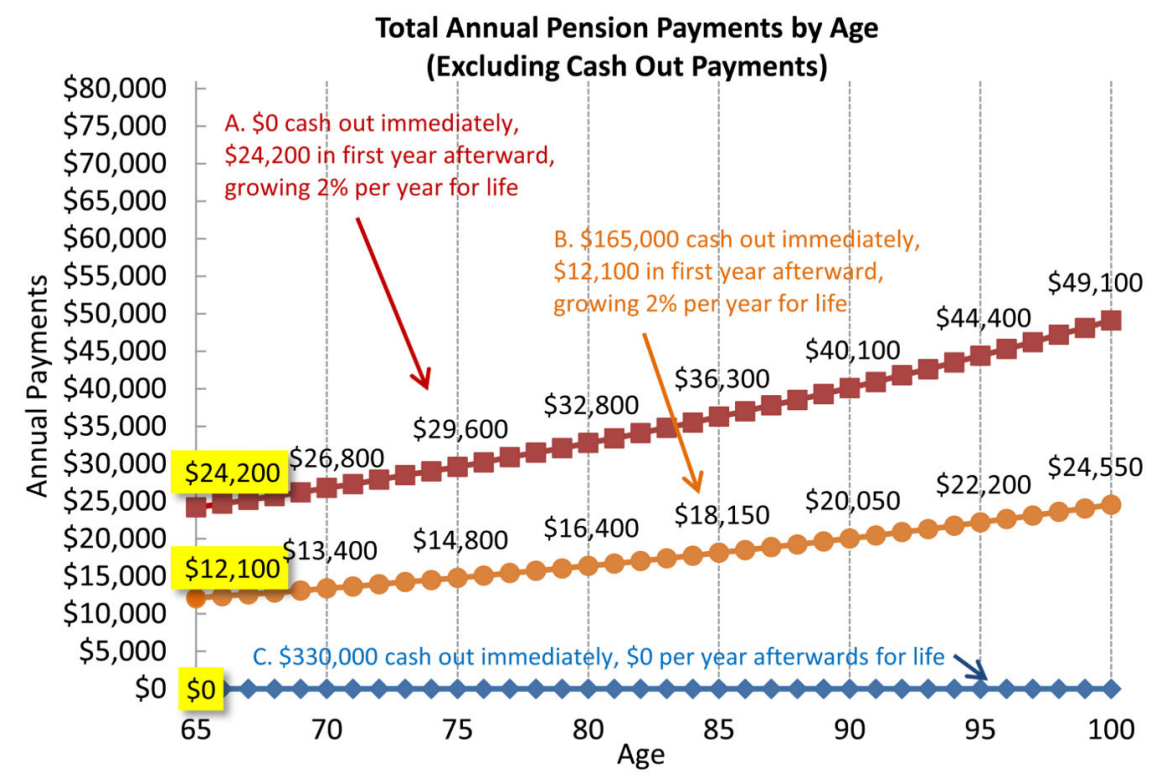

Figure 4. Graph of nominal payments for Match-Inflation cash-out question in Survey 1 
How would you choose to receive your pension payments?

\begin{tabular}{|c|c|c|c|c|}
\hline \multicolumn{3}{|c|}{$\begin{array}{l}\text { Lower lump sum/ } \\
\text { More guaranteed } \\
\text { income }\end{array}$} & \multicolumn{2}{|c|}{$\begin{array}{r}\text { Higher lump sum/ } \\
\text { Less guaranteed } \\
\text { income }\end{array}$} \\
\hline $\begin{array}{l}0 \% \text { lump sum, } 100 \% \\
\text { guaranteed income (\$0 } \\
\text { up front, \$2,981 } \\
\text { monthly payment) }\end{array}$ & $\begin{array}{c}25 \% \text { lump sum, } 75 \% \\
\text { guaranteed income } \\
\text { (\$125,000 up front, } \\
\$ 2,235.75 \text { monthly } \\
\text { payment) }\end{array}$ & $\begin{array}{c}50 \% \text { lump sum, } 50 \% \\
\text { guaranteed income } \\
\text { (\$250,000 up front, } \\
\$ 1,490.50 \text { monthly } \\
\text { payment) }\end{array}$ & $\begin{array}{c}75 \% \text { lump sum, } 25 \% \\
\text { guaranteed income } \\
\text { (\$375,000 up front, } \\
\$ 745.25 \text { monthly } \\
\text { payment) }\end{array}$ & $\begin{array}{r}100 \% \text { lump } \\
\text { guarantee } \\
(\$ 500,000 \mathrm{u} \\
\text { monthly } \mathrm{p}\end{array}$ \\
\hline
\end{tabular}

Figure 5. Minimal Framing initial choice screen for unmarried subjects in Survey 2 


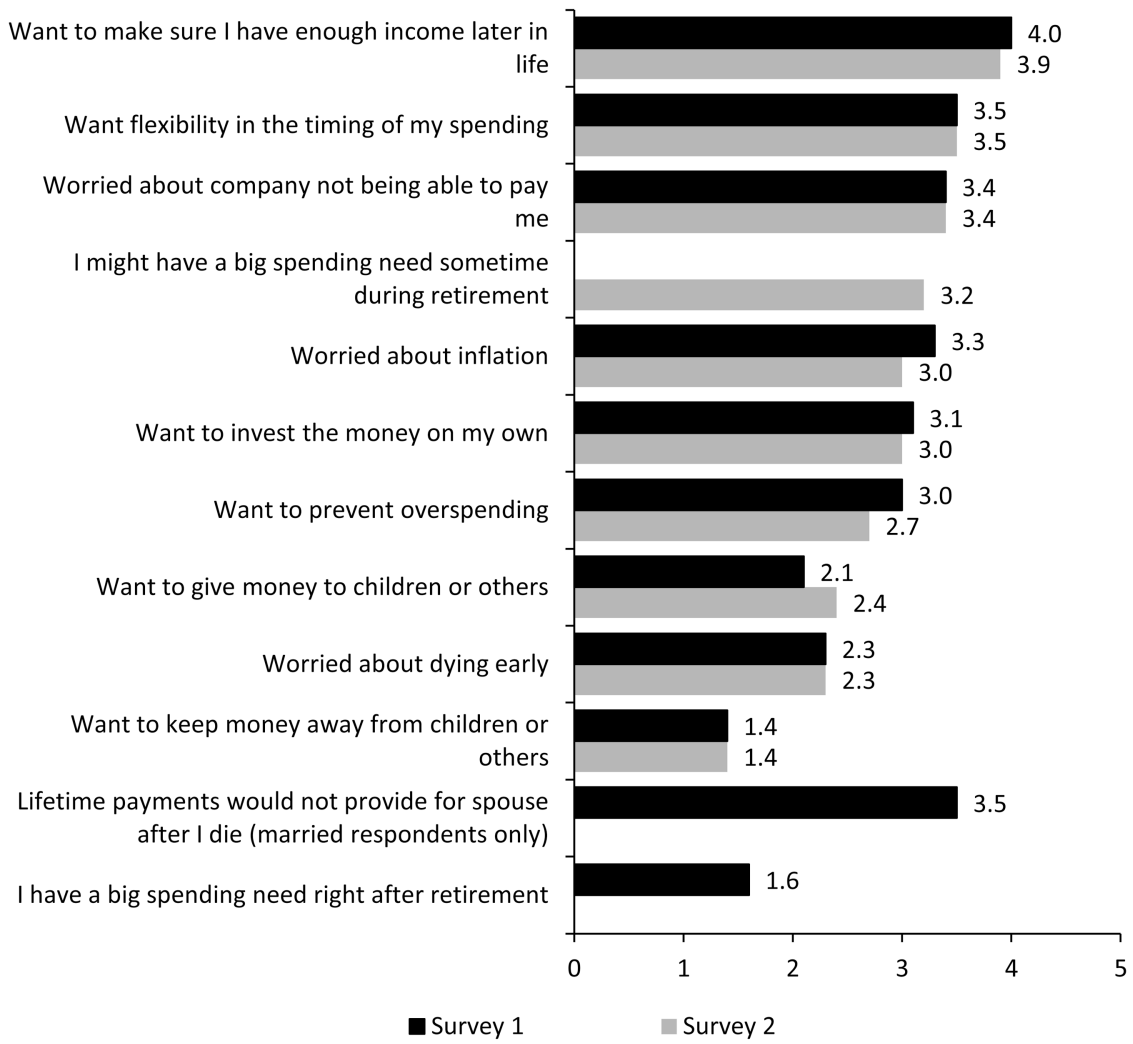

Figure 6. Average reported importance of motives for lump sum vs. annuity choices Source: Authors' calculations 


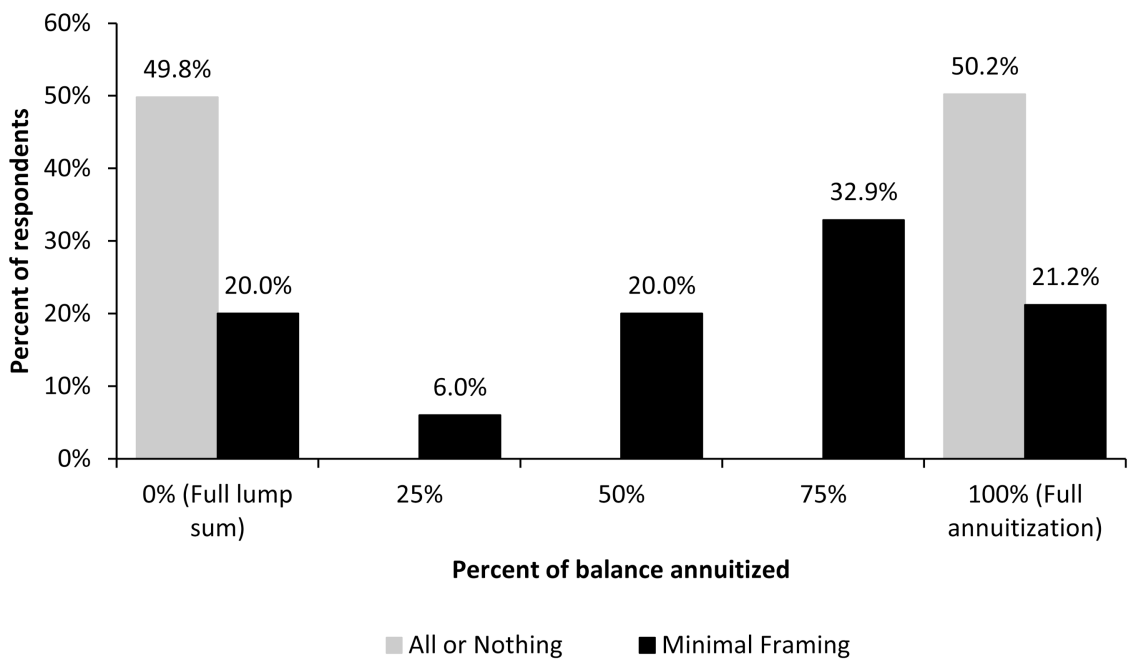

Figure 7. Distribution of percent of balance annuitized in Survey 2 before seeing mortality chart under the All or Nothing treatment and Minimal Framing baseline

Source: Authors' calculations 


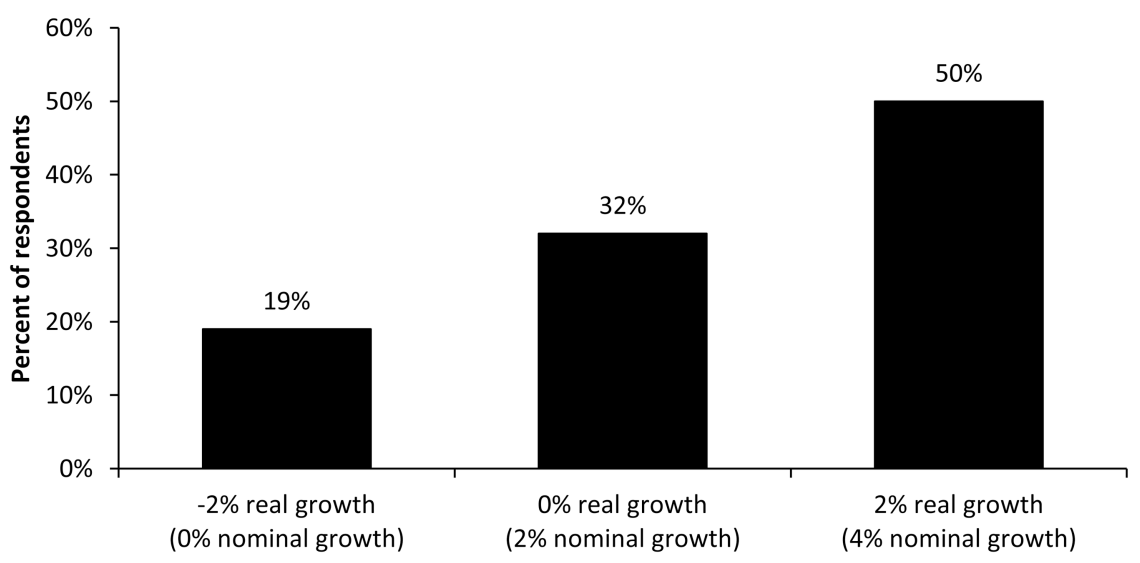

Figure 8. What slopes do people prefer for their annuity payouts in Survey 1?

Source: Authors' calculations. This figure reports the percent of respondents in Survey 1 who most prefer the indicated intertemporal slope of annuity payouts. The sample is restricted to respondents with single-peaked preferences over payout slopes. 


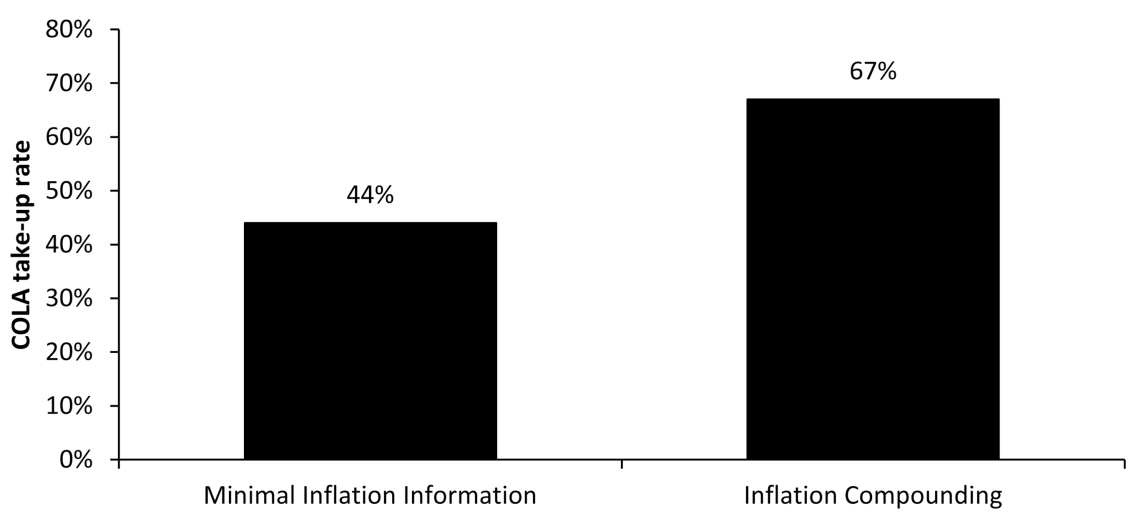

Figure 9. COLA take-up rates in the Minimal Inflation Information baseline and the Inflation Compounding treatment, Survey 2

Source: Authors' calculations. This figure reports the percent of respondents who chose to add a COLA to their annuity in the Minimal Inflation Information baseline and the Inflation Compounding treatment. 


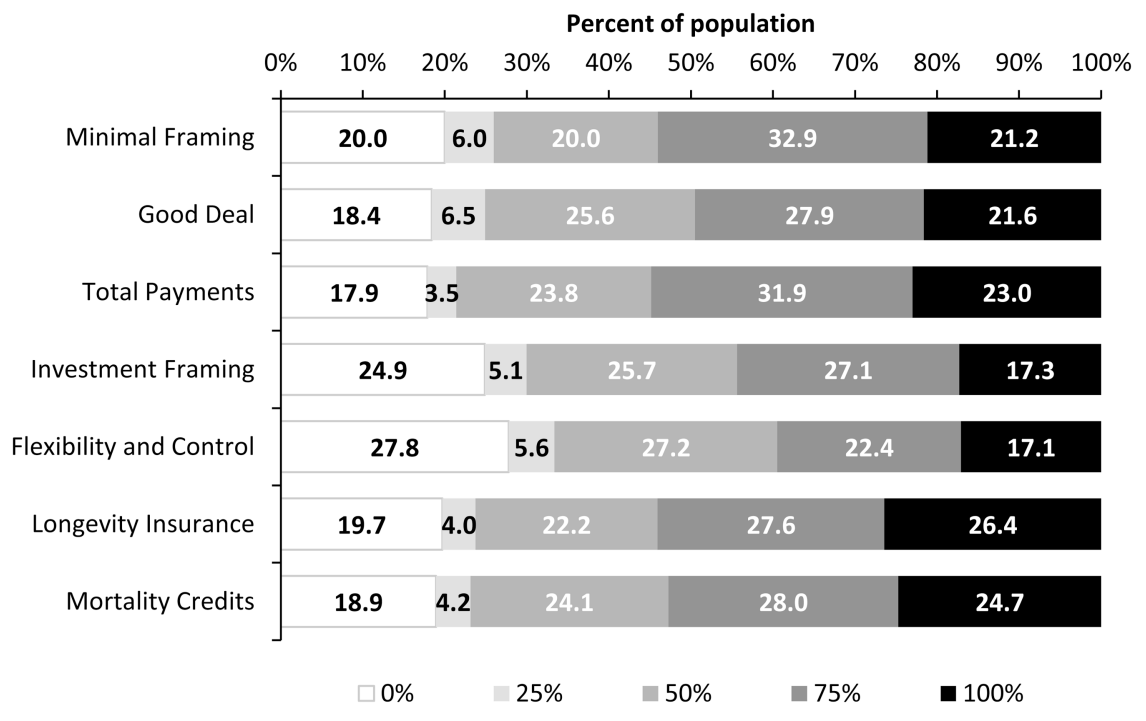

Figure 10. Distribution of percent of balance annuitized before seeing mortality chart in Survey 2 across frames 


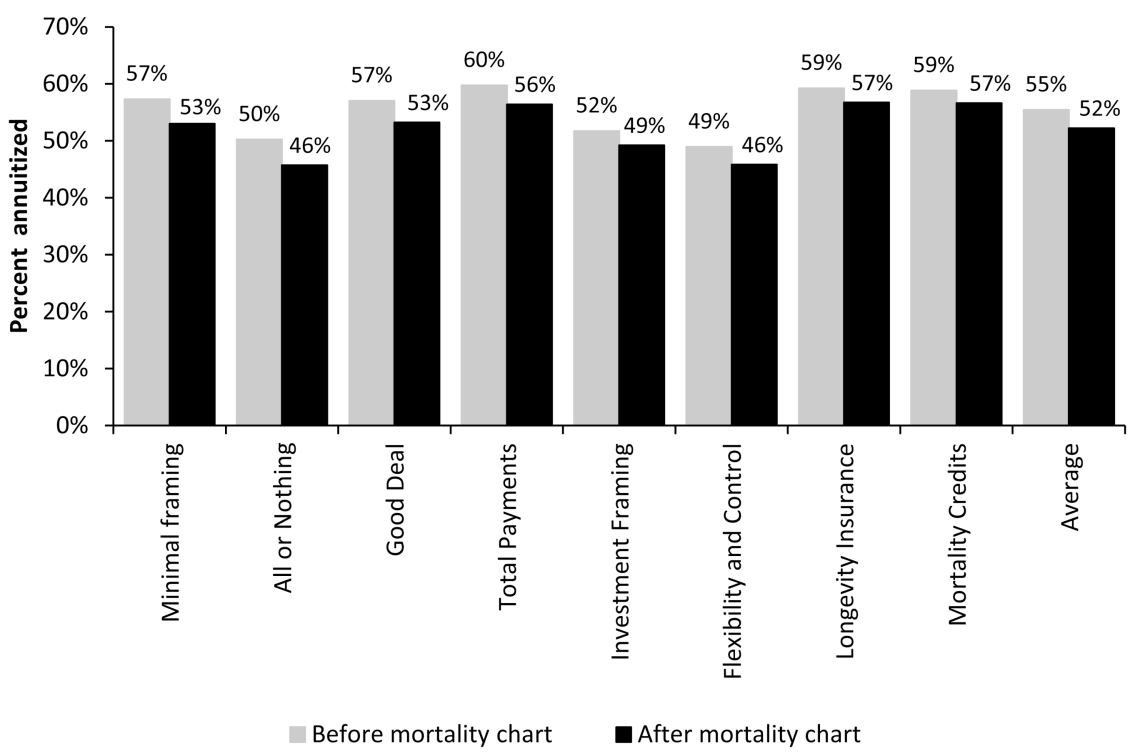

Figure 11. Average percent of balances annuitized in Survey 2 before and after seeing mortality chart

Source: Author' calculations 


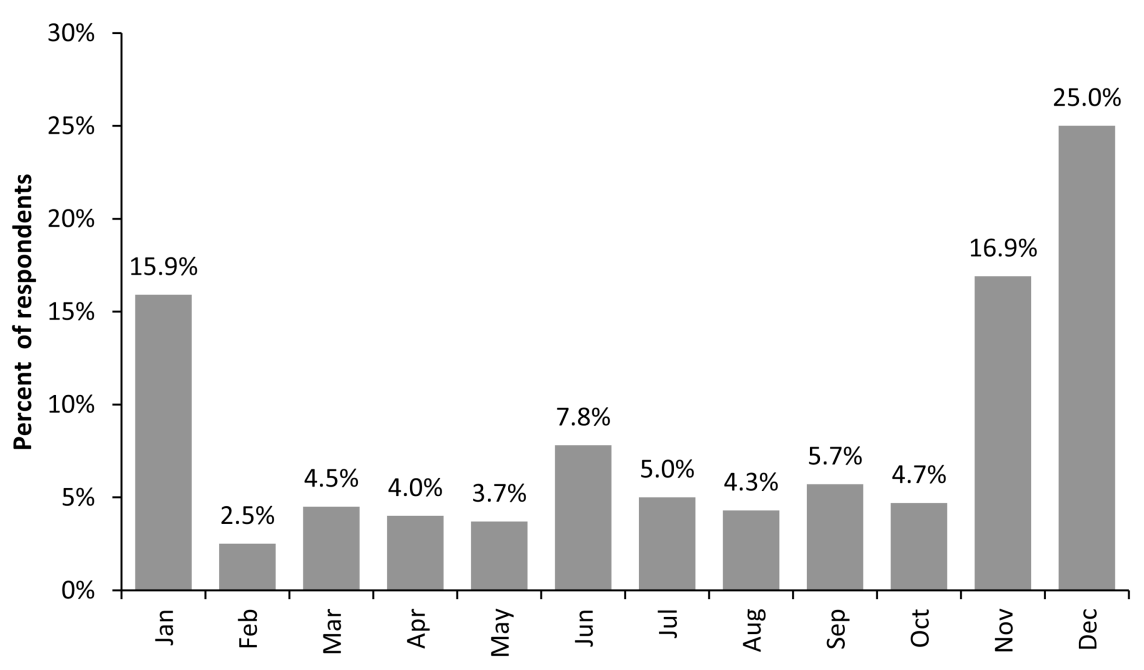

Figure 12. Month chosen for bonus payment in Survey 1

Source: Author' calculations 
Table 1

Survey clarity assessment by survey participants

\begin{tabular}{|c|c|c|}
\hline Assessment of clarity & Survey 1 & Survey 2 \\
\hline Clear & $53.0 \%$ & $64.3 \%$ \\
\hline Mostly clear & $33.8 \%$ & $28.2 \%$ \\
\hline Sometimes clear & $4.7 \%$ & $3.2 \%$ \\
\hline Sometimes confusing & $7.8 \%$ & $3.2 \%$ \\
\hline Mostly confusing & $0.1 \%$ & $0.4 \%$ \\
\hline Completely confusing & $0.3 \%$ & $0.2 \%$ \\
\hline Decline to answer & $0.3 \%$ & $0.4 \%$ \\
\hline Total & $100 \%$ & $100 \%$ \\
\hline
\end{tabular}

Source: Authors' calculations 
Table 2

Participant characteristics

\begin{tabular}{lccc}
\hline & Survey 1 & Survey 2 \\
Age (mean) & 59.5 & 59.6 \\
Male & $50.2 \%$ & $49.6 \%$ \\
Married & $55.4 \%$ & $54.5 \%$ \\
Number of children (mean) & 2.1 & 2.0 \\
Retired & $35.6 \%$ & $40.3 \%$ \\
Have a DB pension & $39.3 \%$ & $37.6 \%$ \\
Own home & $71.3 \%$ & $69.5 \%$ \\
Net worth (among respondents) & & \\
Median & $\$ 162,500$ & & $\$ 150,000$ \\
Mean & $\$ 298,217$ & & $\$ 286,594$ \\
Highest education attained & & \\
No high school diploma & $1.9 \%$ & $1.7 \%$ \\
High school diploma & $22.9 \%$ & $23.8 \%$ \\
Some college & $35.0 \%$ & $35.8 \%$ \\
College degree & $27.1 \%$ & $26.6 \%$ \\
Graduate degree & $12.8 \%$ & $11.8 \%$ \\
Decline to answer & $0.3 \%$ & $0.3 \%$ \\
Life expectancy & & \\
Longer than the average person my age & $36.4 \%$ & $33.9 \%$ \\
About the same as the average person my age & $54.1 \%$ & $54.3 \%$ \\
Shorter than the average person my age & $9.5 \%$ & $11.8 \%$ \\
\hline
\end{tabular}

Source: Authors' calculations 


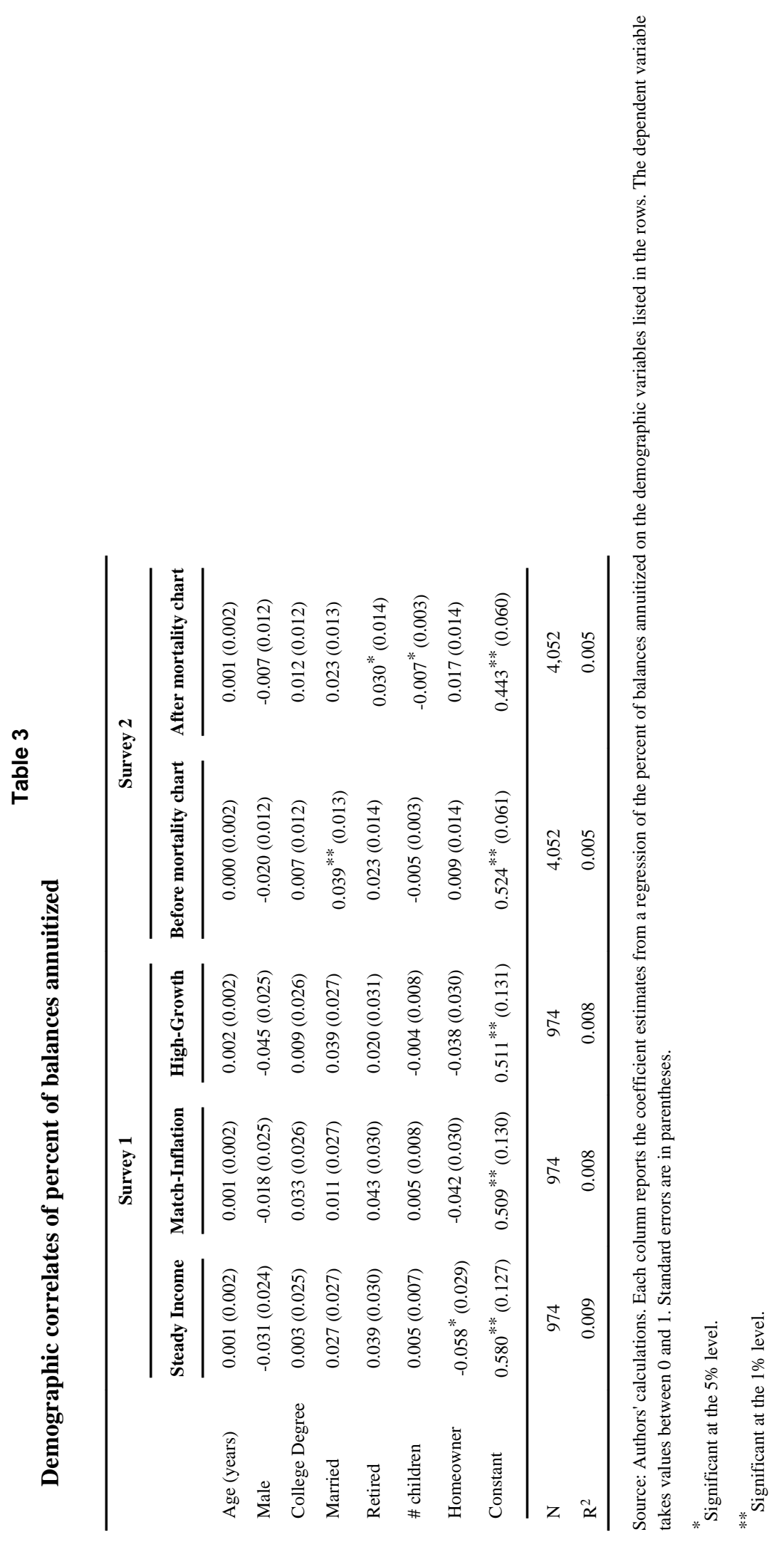

J Public Econ. Author manuscript; available in PMC 2015 August 01. 
Table 4

Association between annuitization percentage before seeing mortality graph and factor importance ratings in Survey 2

\begin{tabular}{ll}
\hline Income later in life & $0.05^{* *}(0.01)$ \\
Flexibility in spending timing & $-0.04^{* *}(0.01)$ \\
Company might not pay me & $-0.06^{* *}(0.01)$ \\
Spending need sometime during retirement & $-0.00(0.01)$ \\
Worried about inflation & $0.01(0.01)$ \\
Want to invest money on my own & $-0.11^{*}(0.01)$ \\
Prevent overspending & $0.06^{* *}(0.01)$ \\
Give money to children or others & $-0.01^{*}(0.01)$ \\
Worried about dying early & $-0.04^{* *}(0.01)$ \\
Keep money from children or others & $0.00(0.01)$ \\
Constant & $0.55^{* *}(0.01)$ \\
\hline $\mathrm{N}$ & 4,130 \\
\hline
\end{tabular}

Source: Authors' calculations. This table reports the coefficient estimates from a regression of the percent of balances annuitized on respondents' factor importance ratings for their lump sum versus annuity choices. The dependent variable takes values between 0 and 1 . Each factor importance rating is standardized to have mean zero and variance one. Standard errors are in parentheses.

* Significant at the $5 \%$ level.

**

Significant at the $1 \%$ level. 
Table 5

Effect of framing on annuity choices before seeing mortality graph in Survey 2

\begin{tabular}{lcc}
\hline & \multicolumn{2}{c}{ Annuity outcome } \\
\cline { 2 - 3 } & Any balances annuitized (0/1) & Percent of balances annuitized \\
\hline Framing treatments & - & -- \\
Minimal framing treatment (omitted) & $0.020(0.025)$ & $-0.002(0.022)$ \\
Good Deal treatment dummy & $0.017(0.025)$ & $0.019(0.022)$ \\
Total Payments treatment dummy & $-0.048(0.026)$ & $-0.060^{* *}(0.022)$ \\
Investment Framing treatment dummy & $-0.078^{* *}(0.026)$ & $-0.087^{* *}(0.022)$ \\
Flexibility and Control treatment dummy & $0.004(0.025)$ & $0.017(0.022)$ \\
Longevity Insurance treatment dummy & $0.010(0.026)$ & $0.014(0.022)$ \\
Mortality Credits treatment dummy & & $0.000(0.001)$ \\
Other controls & $-0.002(0.001)$ & $-0.019(0.012)$ \\
Age & $-0.023(0.014)$ & $0.003(0.012)$ \\
Male dummy & $-0.000(0.014)$ & $0.041^{* *}(0.013)$ \\
Has college degree dummy & $0.002(0.015)$ & $0.025(0.014)$ \\
Married dummy & $0.013(0.017)$ & $-0.003(0.003)$ \\
Retired dummy & $-0.001(0.004)$ & $0.010(0.014)$ \\
Number of children & $0.010(0.016)$ & $0.546^{* *}(0.062)$ \\
Homeowner dummy & $0.899^{* *}(0.072)$ & 3,547 \\
Constant & 3,547 & 0.017 \\
\hline $\mathrm{N}$ & 0.009 & \\
$\mathrm{R}^{2}$ & & \\
\hline
\end{tabular}

Source: Authors' calculations. This table reports the coefficient estimates from regressions of annuitization outcomes on a set of framing treatment indicator variables and a set of demographic variables. The dependent variable in first column is an indicator variable (0/1) for whether any balances were annuitized. The dependent variable in the second column, the percent of balances annuitized, takes values of $0,0.25,0.50,0.75$, or 1.0. The sample excludes participants in the "All or Nothing" treatment. Standard errors are in parentheses.

Significant at the $5 \%$ level.

**

Significant at the $1 \%$ level. 